\title{
Potential negative effects of anti-histamines on male reproductive function
}

\author{
Carolina Mondillo¹, María Luisa Varelaํ, Adriana María Belén Abiuso ${ }^{1}$ and Ramiro Vázquez ${ }^{2}$ \\ 'Laboratorio de Endocrinología Molecular y Transducción de Señales, Instituto de Biología y Medicina Experimental \\ (IBYME-CONICET), Buenos Aires, Argentina and ' 2 Laboratory of Experimental Therapeutics, Institute of Oncology \\ Research (IOR), Bellinzona, Switzerland
}

Correspondence should be addressed to C Mondillo; Email: carolina.mondillo@gmail.com

\begin{abstract}
Histamine (HA) is a pleiotropic biogenic amine synthesized exclusively by histidine decarboxylase (HDC) in most mammalian tissues. The literature on the role of $\mathrm{HA}$ within the male gonad has expanded over the last years, attracting attention to potential unexpected side-effects of anti-histamines on testicular function. In this regard, HA receptors (HRH1, HRH2 and HRH4) have been described in Leydig cells of different species, including human. Via these receptors, HA has been reported to trigger positive or negative interactions with the LH/hCG signaling pathway depending upon its concentration, thereby contributing to the local control of testicular androgen levels. It should then be considered that anti-histamines may affect testicular homeostasis by increasing or decreasing steroid production. Additionally, $\mathrm{HRH} 1$ and $\mathrm{HRH} 2$ receptors are present in peritubular and germ cells, and $\mathrm{HRH} 2$ antagonists have been found to negatively affect peritubular cells and reduce sperm viability. The potential negative impact of anti-histamines on male reproduction becomes even more dramatic if we consider that HA has also been associated with human sexual behavior and penile erection. What is more, although testicular mast cells are the major source of locally produced HA, recent studies have described HDC expression in macrophages, Leydig cells and germ cells, revealing the existence of multiple sources of HA within the testis. Undoubtedly, the more we learn about the testicular histaminergic system, the more opportunities there will be for rational design of drugs aimed at treating HA-related pathologies, with minimum or nule negative impact on fertility.

Reproduction (2018) 155 R221-R227
\end{abstract}

\section{Introduction}

Undeniably, histamine (HA) is a biogenic amine with great significance in medicine and biology. It is produced by $\alpha$-decarboxylation of L-histidine, and this reaction is catalyzed exclusively by histidine decarboxylase (HDC) in most mammalian tissues (Ohtsu 2010). Since its discovery in 1910, HA has been shown to mediate a plethora of physiological and pathological actions via its four $\mathrm{G}$ protein-coupled receptors, named $\mathrm{H} 1, \mathrm{H} 2$, H3 and $\mathrm{H} 4$ (histamine receptor $\mathrm{H} 1(\mathrm{HRH} 1)-\mathrm{HRH} 4)$, which are differentially expressed in numerous cell types (Akdis \& Simons 2006, Parsons \& Ganellin 2006). In particular, the literature on the relation between $\mathrm{HA}$ and male reproduction has greatly expanded over the past years, resulting in the identification of novel functions for $\mathrm{HA}$ within the male reproductive system of several species, including human. This review summarizes what is presently known regarding the effects of $\mathrm{HA}$ on the different cell types of the testis, with special focus on Leydig cells. Potential local sources of HA other than testicular mast cells are also described, as well as adverse effects of anti-histamines on normal testis function. The rising prevalence of allergic diseases in the industrialized world underscores the significance of this topic.

\section{Histamine and Leydig cell steroidogenesis}

Evidence accumulated so far indicates the presence of functional $\mathrm{HRH} 1$ and $\mathrm{HRH} 2$ in Leydig cells of mouse, rat, human and the ectothermic vertebrate Hemidactylus flaviviridis (Mayerhofer et al. 1989, Albrecht et al. 2005, Mondillo et al. 2005, 2007, 2009, Khan \& Rai 2007). In line with these findings, $\mathrm{HA}$ has been reported to exert a biphasic effect on steroidogenesis in the MA-10 mouse Leydig tumor cell line and in rat Leydig cells in primary culture, depending upon its concentration: while nanomolar HA stimulates basal steroid production and enhances the steroidogenic response to luteinizing homone (LH)/ human chorionic gonadotropin (hCG), micromolar concentrations display a potent anti-steroidogenic effect (Mondillo et al. 2005). Accordingly, in the wall lizard H. flaviviridis, although HA does not affect testosterone production from unstimulated Leydig cells, it has dual 
concentration-related effects on follicle-stimulating hormone (FSH)-induced testosterone production: stimulatory at a low concentration of $10^{-10} \mathrm{M}$ while inhibitory at a high concentration of $10^{-5} \mathrm{M}$ (Khan \& Rai 2007). Based on these and subsequent publications (Mondillo et al. 2005, 2007, 2009, Khan \& Rai 2007), HA-induced stimulation of steroidogenesis would primarily be mediated via $\mathrm{HRH} 2$ activation, which signals by Gs protein coupling and increased cAMP production (Fig. 1), whereas reduction of steroid levels by micromolar HA would involve HRH1 activation, Gq protein coupling, stimulation of the phospholipase $\mathrm{C}(\mathrm{PLC})$ /inositol 1,4,5-triphosphate $\left(\mathrm{IP}_{3}\right)$ pathway and increased nitric oxide synthase (NOS) activity (Fig. 2) (Mondillo et al. 2009). Very recently, HRH4 has been identified in mouse and rat Leydig cells, in agreement with a previous report by O'Reilly et al. (2002), which indicated HRH4 expression in the human testis (Abiuso et al. 2014). Considering that activation of HRH4 on Leydig cells with specific agonists leads to a decreased steroidogenic response to $\mathrm{LH} / \mathrm{hCG}$, it is tempting to speculate that $\mathrm{HRH} 4$ may also participate in the aforesaid inhibitory effect of HA on steroid synthesis (Fig. 2). Indeed, synergistic effects between HRH1 and $\mathrm{HRH} 4$ have been described in other cell types, in which HRH1 colocalizes with HRH4 (Thurmond et al. 2008, Deiteren et al. 2014). Having opposing effects on steroidogenesis by triggering positive or negative interactions with the LH/hCG signaling pathway, HA can control androgen levels, thereby contributing to testicular homeostasis. This new role for $\mathrm{HA}$ in the physiological regulation of Leydig cell function is further supported by studies showing that, in HA-deprived HDC-knockout (KO) mice, the steroidogenic efficiency of Leydig cells is significantly lower in comparison with wild-type (WT) mice (Mondillo et al. 2005). In this regard, it has been shown that HDC KO Leydig cells do not respond to $\mathrm{LH} /$ hCG as effectively as WT Leydig cells (Mondillo et al. 2007) and that LH/hCG stimulus induces Hrh 1 and Hrh2 expression in WT Leydig cells, while this does not occur in KO mice (Mondillo et al. 2005).

\section{Histamine and Leydig cell proliferation}

Pap and coworkers (2002) have reported serious alterations in Leydig cell ultrastructure in adult HDC KO mice, and a significant reduction in testicular weight in litters as early as 7 days of age (Pap et al. 2002). Notably, the distribution and morphology of gonadotropinreleasing hormone $(\mathrm{GnRH})$ neurons is normal in these mice, as well as hypothalamic Gnrh1 mRNA expression (Pap et al. 2002). Hence, even when the major role of LH as a modulator of Leydig cell morphology and function is undisputable (Lejeune et al. 1996), the lack of endogenous $\mathrm{HA}$ production in $\mathrm{HDC} \mathrm{KO}$ mice may presumably result in changes during the course of embryonic testicular ontogenesis, leading to deficient adult Leydig cell function. This theory is reinforced by former scientific evidence showing that testicular HDC expression and HA concentration are significantly elevated in the neonatal testis compared to the adult gonad (Zieher et al. 1971, Pagotto et al. 2012), implying

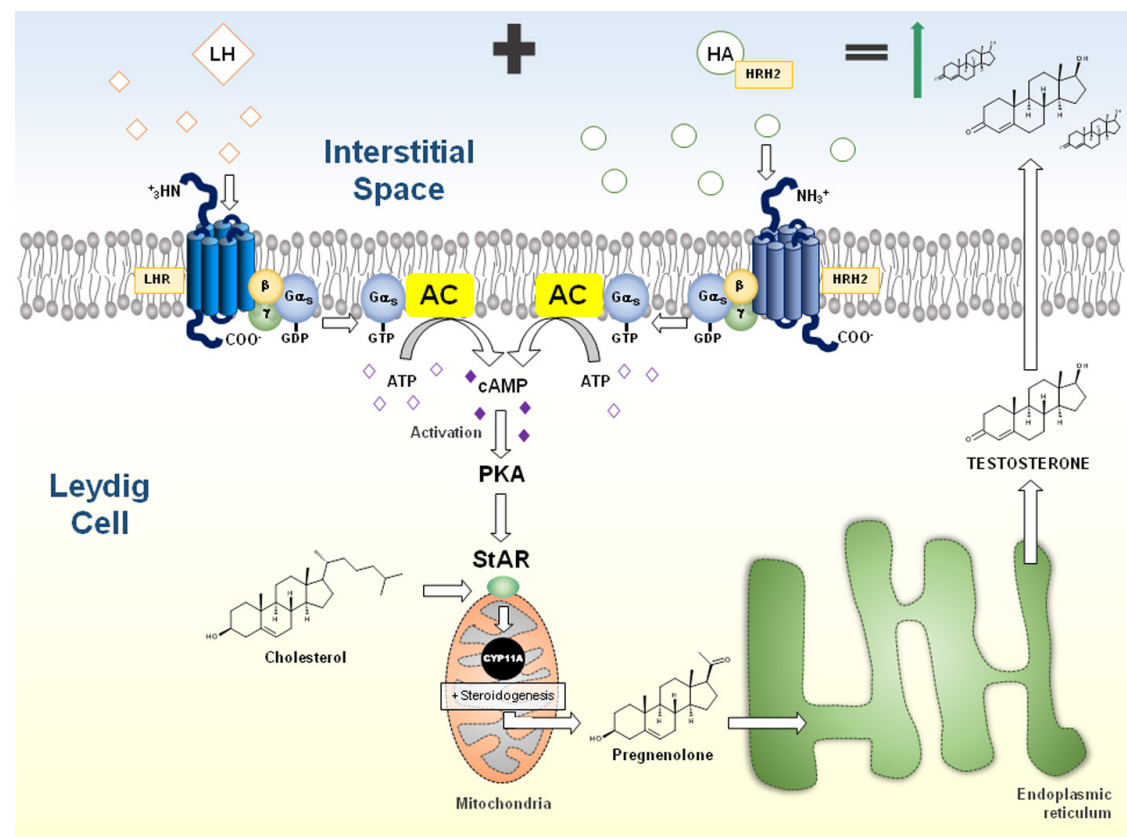

Figure 1 Proposed mechanism for HA-mediated enhancing effect on $\mathrm{LH}$-induced testosterone synthesis in Leydig cells via $\mathrm{HRH}$. AC, Adenylate cyclase; ATP, Adenosine triphosphate; cAMP, cyclic adenosine monophosphate; LH, luteinizing hormone; LHR, luteinizing hormone receptor; PKA, Protein kinase A. 


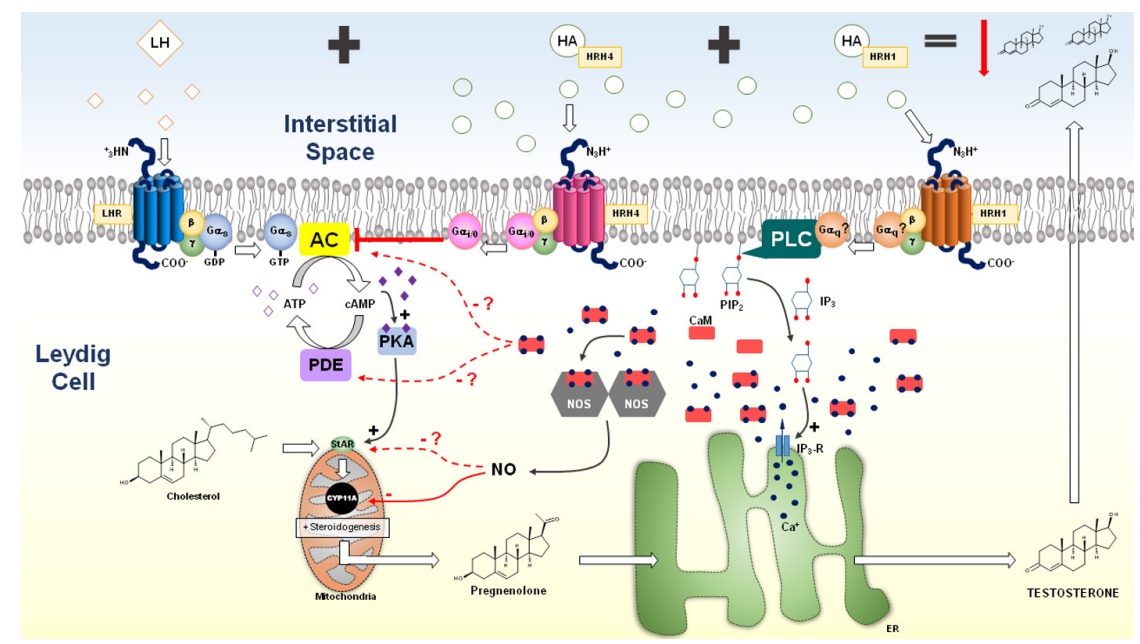

Figure 2 Proposed mechanism by which HA down-regulates LH/hCG-induced testosterone production via HRH1 and HRH4 activation in Leydig cells. NOS, nitric oxide synthase; PDE, phosphodiesterase E; PLC, phospholipase C.

that important HA-dependent events may occur during the development of the testis. Consistently, Gaytan et al. (1992) have observed that proliferation and differentiation of mast cells and Leydig cells happen at the same time in the rat testis, suggesting the existence of a dynamic relationship between the two cell types via their secretory products (Gaytan et al. 1992). It is tempting to speculate, in view of the aforementioned observations in HDC KO mice and the fact that $\mathrm{HA}$ is a well-known regulator of cell proliferation (Falus et al. 2010), that HA could be one of the mast cell-derived local factors influencing Leydig cell number in the neonatal testis. This would not be the case in the adult gonad. In this regard, HA fails to affect FSH-stimulated adult Leydig cell proliferation in the wall lizard (H. flaviviridis) (Khan \& Rai 2007). Also, it has been demonstrated that immature and progenitor Leydig cells, isolated from 21- and 35-day-old rats, respectively, do not exhibit a proliferative response upon stimulation with $\mathrm{HA}$, whereas they proliferate when stimulated with insulin-like growth factor type 1 (IGF1) (Pagotto et al. 2012). Interestingly, HA can stimulate the proliferation of MA-10 Leydig tumor cells via activation of $\mathrm{HRH} 2$, transient elevation of cAMP production and increased extracellular signal-regulated kinase (ERK) phosphorylation (Pagotto et al. 2012). Indeed, MA-10 cells show significantly heightened HDC expression compared to normal immature Leydig cells or whole testicular lysate, and inhibition of HDC activity decreases MA-10 cell proliferation. These results suggest that autocrine overproduction of HA might be somewhat linked to abnormally increased proliferation in Leydig cells, as occurs in numerous cell types (Adams et al. 1994, Ai et al. 2006, Falus et al. 2010). Thus, although the possibility that HA may influence Leydig cell numbers in the normal fetal and/or neonatal testis certainly deserves further research, a putative role for $\mathrm{HA}$ as an autocrine/paracrine modulator of Leydig cell proliferation in testicular pathological states should also be considered.

\section{Testicular histamine targets other than Leydig cells}

Aside from Leydig cells, germ cells, peritubular cells and macrophages of different species express HRH1 and/or $\mathrm{HRH} 2$ receptors and are therefore potential targets for locally produced HA (Albrecht et al. 2005, Khan \& Rai 2007). In this respect, as observed in Leydig cells, in the wall lizard (H. flaviviridis), HA-regulated testicular macrophage immune responses in a dual concentrationdependent manner (Khan \& Rai 2007). It inhibited phagocytosis and superoxide production at a high concentration $\left(10^{-5} \mathrm{M}\right)$, while stimulated superoxide production and could not affect phagocytosis at a low concentration $\left(10^{-10} M\right)$ (Khan \& Rai 2007). With regard to peritubular cells, it was not until very recently that they were found to be regulated by mast cell and macrophage products, and in response, produce factors that can fuel inflammatory changes. Also, recent studies have revealed that peritubular cells transport immotile sperm - a function important for male fertility, produce extracellular matrix components and contribute to the spermatogonial stem cell niche via secreted factors (Mayerhofer 2013). The fact that these cells bare HRH1 receptors opens the question whether HA may directly influence the aforementioned functions. This possibility has not been explored yet. No studies have been done on isolated Sertoli cells or endothelial cells, but it is tempting to speculate, in view of indirect evidence in cells derived from the testicular germinal region and the fact that vascular cells are known to respond to $\mathrm{HA}$, that such cells are also targets of $\mathrm{HA}$. With regard to the latter point, the action of $\mathrm{HA}$ on most of the endothelial cells and tissue barriers has been recently demonstrated (Adderley et al. 2015, Ashina et al. 2015). Additionally, 


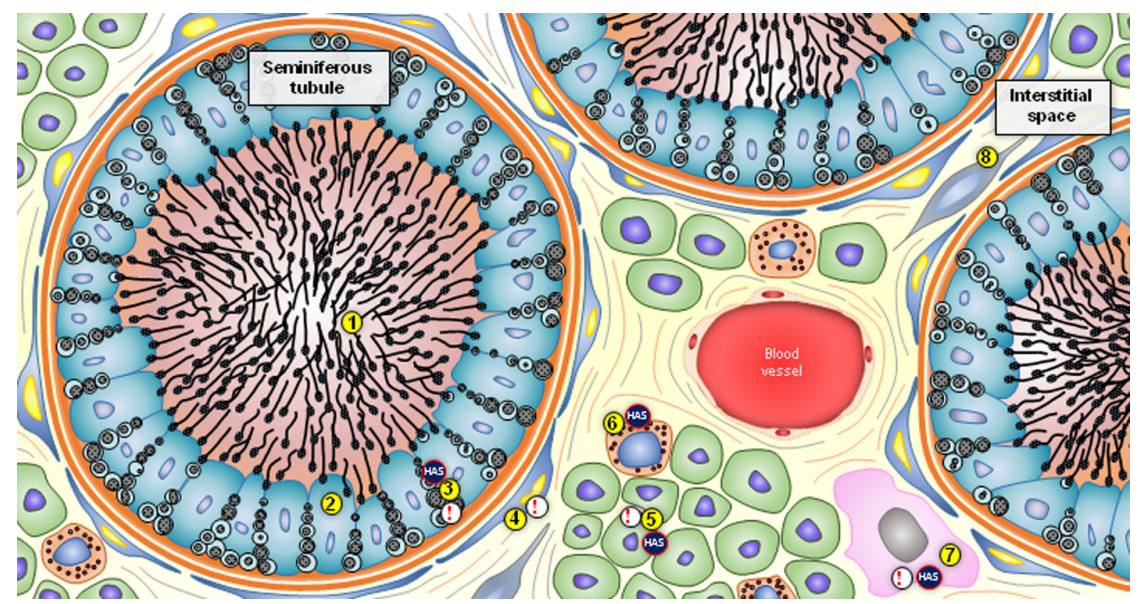

Figure 3 Schematic representation of the adult human testis indicating potential sources of HA as well as HA-target cells. (1) spermatozoa, (2) Sertoli cell, (3) germ cells, (4) peritubular cell, (5) Leydig cell, (6) mast cell/basophil, (7) macrophage, (8) fibroblast. HAS, Histamine (HA) source; !, Target for locally produced $\mathrm{HA}$ and/or histaminergic drugs.

a very old publication has documented blood-testis barrier impairment by administration of the HA releaser 48/80 to guinea pigs (Nemetallah et al. 1985).

\section{Multiple sources of histamine within the testis}

Although testicular mast cells are the major source of local HA, recent studies have revealed the existence of multiple potential sources of HA within the testis. In this regard, HDC expression has been detected in macrophages, Leydig cells (as indicated in a previous section of this manuscript) and germ cells (Safina et al. 2002, Albrecht et al. 2005, Pagotto et al. 2012). Interestingly, a similar scenario has been described in the female uterus and mammary gland. In both organs, mast cell-derived HA and epithelial cell-derived HA regulate physiological functions (Paria et al. 1998, Wagner et al. 2003). Whether non-mast cell-related HA has a crucial role in testicular physiology is yet unclear. However, the presence of multiple HA-synthesizing cells in the different compartments of the testis highlights the significance of local HA production and should definitely arouse interest in the potential deleterious effects of long-term anti-histamine therapy on both the endocrine and reproductive functions of the male gonad. Figure 3 and Table 1 show the different cellular targets of HA within the testis, as well as potential nonmast cell HA sources.

\section{Negative impact of anti-histamines on male reproduction}

Considering the diversity of syndromes associated with $\mathrm{HA}$, in recent years, a wide variety of anti-histamine compounds have been introduced in the clinics for the treatment of these diseases, particularly $\mathrm{HRH} 1$ and
$\mathrm{HRH} 2$ antagonists such as loratadine, desloratadine, cimetidine, ranitidine, nizatidine and famotidine, among others. Moreover, the discovery of $\mathrm{HRH} 4$ revitalized the interest in HA receptor pharmacology, leading to a considerable increase in $\mathrm{HRH} 4$-related publications and patents (Leurs et al. 2009, Schreeb et al. 2013). Clinicians and patients should be aware, though, that the overuse of anti-histamines could have long-term side effects on the various target organs of HA, at best only reversible. More particularly, concerning the male gonad, the new role for $\mathrm{HA}$ as a modulator of Leydig cell function clearly suggests that anti-histamine drugs may affect testicular homeostasis by enhancing or decreasing androgen production (Mondillo et al. 2005, 2007, 2009, Khan \& Rai 2007). In this respect, it has been reported that ingesting around $1200 \mathrm{mg} /$ day cimetidine can decrease testosterone levels (Elliott 1979, Fuentes \& Dolinsky 1979, Babb 1980). Additionally, cimetidine was found to lower the sperm count in humans, especially at doses greater than $1000 \mathrm{mg}$ /day (Elliott 1979, Fuentes \& Dolinsky 1979, Babb 1980, Wang et al. 1982, Buchanan \& Davis 1984, Van Thiel et al. 1987), while it exerted moderate effects on sperm morphology and motility (Wang et al. 1982, Thomas

Table 1 Potential sources of HA and HA targets within the testis.

\begin{tabular}{lccccc}
\hline & $\begin{array}{l}\text { Potential } \\
\text { HA source }\end{array}$ & & \multicolumn{3}{c}{$\begin{array}{c}\text { Targets for locally } \\
\text { produced HA }\end{array}$} \\
\cline { 2 - 3 } \cline { 5 - 7 } Cell type & HDC & & HRH1 & HRH2 & HRH4 \\
\hline Germ cell & + & & + & + & ND \\
Sertoli cell & $\mathrm{ND}$ & & $\mathrm{ND}$ & $\mathrm{ND}$ & $\mathrm{ND}$ \\
Peritubular cell & $\mathrm{ND}$ & & + & $\mathrm{ND}$ & $\mathrm{ND}$ \\
Leydig cell (LC) & + & & + & + & + \\
Mast cell/Basophil & + & & $\mathrm{ND}$ & $\mathrm{ND}$ & $\mathrm{ND}$ \\
Macrophage & + & & + & + & $\mathrm{ND}$ \\
Fibroblast & $\mathrm{ND}$ & & $\mathrm{ND}$ & $\mathrm{ND}$ & $\mathrm{ND}$ \\
LC-derived MA-10 cell line & + & & + & + & + \\
\hline
\end{tabular}

$\mathrm{ND}$, not determined. 
\& Turner 1983, Buchanan \& Davis 1984, Bianchi Porro et al. 1985). The deleterious effect of cimetidine on the number of sperm cells was later confirmed by Aprioku et al. (2014) in Wistar rats. Additionally, a previous study carried out by Sinha et al. (2006) in albino rats demonstrated a reduction in sperm count as well as a decrease in sperm morphology and motility after a 15-day cimetidine treatment. Also, Nayeri and Kazerouni (2002) reported that the seminal vesicles of male rats treated with this drug at $100 \mathrm{mg} / \mathrm{kg}$ for 5 weeks had lower weights compared with the seminal vesicles of the untreated group. A putative explanation for the deleterious impact of cimetidine on sperm quality is that it increases intrasperm $\mathrm{Ca}^{2+}$ levels, and $\mathrm{Ca}^{2+}$ elevation has also been shown to reduce sperm viability (Gupta et al. 2004). Moreover, cimetidine has been found to decrease the height of the germinal epithelium and the diameter of seminiferous tubules in the testes of mice when applied at $10-100 \mathrm{mg} /$ day for 15 days (Gill et al. 1991). Consistent results were observed in male albino Wistar rats, which were injected cimetidine intraperitoneally at a dose of $50 \mathrm{mg} / \mathrm{kg}$ for 52 days (Sasso-Cerri \& Miraglia 2002). A subsequent study conducted by Sasso-Cerri \& Cerri (2008) indicated that cimetidine may lead to Sertoli cell detachment and apoptosis, hence negatively affecting sperm quality. In 2009, Sasso-Cerri reinforced his previous results by demonstrating that cimetidine enhances oestrogen receptor beta expression and apoptosis in germ cells of adult male rats (Sasso-Cerri 2009). To date, the effect of ranitidine on semen quality is a matter of debate (Banihani 2016). Famotidine is the only $\mathrm{HRH} 2$ antagonist that has been reported to benefit sperm physiology; nonetheless, non-clinical experiments indicate that its use may have negative effects on some sperm parameters (Banihani 2016). Further clinical studies will be of great significance to more precisely evaluate the effects of famotidine on semen quality. With regard to desloratadine and loratadine Kuzminov et al. (2014) have reported a cytotoxic action in bull spermatozoa. The potential negative impact of anti-histamines on male reproduction becomes even more significant if we consider that HA has been implicated in penile erection and sexual behavior as well as steroidogenesis and spermatogenesis (Cara et al. 1995, Par et al. 2003, Sinha et al. 2006). In this regard, it has been reported that HA can exert a dose-dependent relaxation of isolated human corpus cavernosum smooth muscle, which is inhibited by cimetidine and potentiated in the presence of the HA HRH1 receptor antagonist mepyramine (Penttilae \& Vartiainen 1964, Cará et al. 1995, Teixeira et al. 1998). Aside from the erectile function, some case studies have also suggested an impact of $\mathrm{HA}$ on the ejaculatory response of the adult man (Raja 1999, Holtmann et al. 2003, Labbate 2008). In apparent contradiction, a more recent report indicates a role for $\mathrm{HA}$ in the physiological mechanism modifying human sexual desire following orgasm/ejaculation, rather than an involvement in the maintenance of penile flaccidity or rigidity or the termination of erection (Ükert et al. 2011). These results then reinforce the idea that HA would be a mediator in a neuroendocrine feedback system modulating male sexual function.

\section{State of the art}

An issue of considerable scientific and clinical interest, which certainly deserves further research, is the potential role of HA and/or HA-receptor transport via extracellular vesicles (EV) secreted by testicular cells. Intercellular communication via EV has drawn much attention recently, as EV have been shown to carry a number of bioactive molecules, surface receptors and genetic information that modulate the activities of recipient cells both in normal physiology and pathological conditions (Pitt et al. 2016, Simon et al. 2018). Most, if not all, cell types release EV, which then enter the body fluids (Robbins \& Morelli 2014, Robbins et al. 2016). Within the male reproductive system, this modality of cell-cell crosstalk has solely been described in the epididymis. In this regard, it has been extensively demonstrated that small membranous vesicles named epididymosomes, which are secreted along the epididymal intraluminal compartment, transfer fertility-modulating proteins to the sperm surface (Martin-DeLeon et al. 2015, Sullivan 2016, Simon et al. 2018). Recently, mast cells have been shown to be rich sources of secreted EV (Shefler et al. 2011). These mast cell-derived EV could then influence the development of the male gonad during embryogenesis or its function later in adulthood. Also, histaminergic effects could be provided constantly by EV secreted by other testicular cells expressing HA receptors. Clearly, this hypothesis deserves further research.

\section{Conclusion}

The increasing list of processes relevant to human (patho) physiology in which HA has a preponderant role has prompted researchers in the discipline to strive for the complete elucidation of its functions and the properties of its receptors. The data compiled in this review collectively indicate the crucial involvement of $\mathrm{HA}$ in the orchestration of testicular functions during development and adulthood. Even so, there is still much to learn regarding the complex interplay between HA-synthesizing cells and targets for HA within the male reproductive system. In view of the evidence reviewed herein, the evaluation of potential HA-drug-induced effects on reproductive and sexual health should definitely be made part of clinical studies, in order to develop novel drugs aimed at treating HA-related pathologies with minimum or nule negative impact on fertility. 


\section{Declaration of interest}

The authors declare that there is no conflict of interest that could be perceived as prejudicing the impartiality of this review.

\section{Funding}

Studies mentioned in this review were supported by grants from Agencia Nacional de Promoción Científica y Tecnológica (ANPCYT, PICT 2012 NN$^{\circ} 2776$ and PICT 2015 NN$^{\circ} 2650$ ), Alberto J Roemmers Foundation, Consejo Nacional de Investigaciones Científicas y Técnicas (CONICET, PIP 392) and University of Buenos Aires (UBA, UBACYT 2013-20020120100205).

\section{Acknowledgements}

The authors are very grateful to Dr Omar Pedro Pignataro, Head of the Laboratory of Molecular Endocrinology and Signal Transduction. The authors would like to thank former lab members, namely Drs Zoraida Patrignani, Cecilia Reche, Mariela Marazita, Bárbara Piotrkowski, Romina Pagotto and Casandra Monzón, as well as current members, especially Marcos Besio Moreno, whose valuable contributions are cited in this review.

\section{References}

Abiuso AM, Berensztein E, Pagotto RM, Pereyra EN, Medina V, Martinel Lamas DJ, Besio Moreno M, Pignataro OP \& Mondillo C 2014 H4 histamine receptors inhibit steroidogenesis and proliferation in Leydig cells. Journal of Endocrinology 223 241-253. (https://doi.org/10.1530/ JOE-14-0401)

Adams WJ, Lawson JA \& Morris DL 1994 Cimetidine inhibits in vivo growth of human colon cancer and reverses histamine stimulated in vitro and in vivo growth. Gut 35 1632-1636. (https://doi.org/10.1136/ gut.35.11.1632)

Adderley S, Lawrence C, Madonia E, Olubadewo J \& Breslin J 2015 Histamine activates p38 MAP kinase and alters local lamellipodia dynamics, reducing endothelial barrier integrity and eliciting central movement of actin fibers. American Journal of Physiology 309 C51-C59. (https://doi.org/10.1152/ajpcell.00096.2015)

Ai W, Takaishi S, Wang TC \& Fleming JV 2006 Regulation of L-histidine decarboxylase and its role in carcinogenesis. Progress in Nucleic Acid Research and Molecular Biology 81 231-270. (https://doi.org/10.1016/ S0079-6603(06)81006-8)

Akdis CA \& Simons FE 2006 Histamine receptors are hot in immunopharmacology. European Journal of Pharmacology 533 69-76. (https://doi.org/10.1016/j.ejphar.2005.12.044)

Albrecht M, Frungieri MB, Gonzalez-Calvar S, Meineke V, Kohn FM \& Mayerhofer A 2005 Evidence for a histaminergic system in the human testis. Fertility and Sterility 83 1060-1063. (https://doi.org/10.1016/j. fertnstert.2004.12.002)

Aprioku JS, Ibeachu C \& Amah-Tariah FS 2014 Differential effects of $\mathrm{H} 2$ receptor antagonists on male reproductive function and hepatic enzymes in wistar rats. Asian Journal of Biomedical and Pharmaceutical Sciences 4 1-6.

Ashina K, Tsubosaka Y, Nakamura T, Omori K, Kobayashi K, Hori M, Ozaki H \& Murata T 2015 Histamine induces vascular hyperpermeability by increasing blood flow and endothelial barrier disruption in vivo. PLOS ONE 10 e0132367. (https://doi.org/10.1371/journal.pone.0132367)

Babb RR 1980 Cimetidine: clinical uses and possible side effects. Postgraduated Medical Journal 68 87-93. (https://doi.org/10.1080/003 25481.1980.11715624)

Banihani S 2016 Histamine-2 receptor antagonists and semen quality. Basic and Clinical Pharmacology and Toxicology 118 9-13. (https://doi. org/10.1111/bcp t.12446)
Bianchi Porro G, Ragni G, Ruspa M, Petrillo M \& Barattini G 1985 Long term treatment with cimetidine does not essentially affect the hypothalamic-pituitary-gonadal axis in man. Hepatogastroenterology $3277-80$.

Buchanan JF \& Davis LJ 1984 Drug-induced infertility. Drug Intelligence and Clinical Pharmacy 18 122-132. (https://doi. org/10.1177/106002808401800205)

Cará AM, Lopes-Martins RA, Antunes E, Nahoum CR \& De Nucci G 1995 The role of histamine in human penile erection. British Journal of Urology 75 220-224. (https://doi.org/10.1111/j.1464-410X.1995.tb07315.x)

Deiteren A, De Man JG, Ruyssers NE, Moreels TG, Pelckmans PA \& De Winter BY 2014 Histamine H4 and H1 receptors contribute to postinflammatory visceral hypersensitivity. Gut 63 1873-1882. (https:// doi.org/10.1136/gutjnl-2013-305870)

Elliott J 1979 Side effects of cimetidine use coming under scrutiny. Journal of the American Medical Association 242 13. (https://doi.org/10.1001/ jama.242.1.13)

Falus A, Po's Z \& Darvas Z 2010 Histamine in normal and malignant cell proliferation. In Histamine in Inflammation, pp 109-123. Ed RL Thurmond. San Diego: Landes Bioscience and Springer Science+ Business Media.

Fuentes RJ Jr \& Dolinsky D 1979 Endocrine function after cimetidine. New England Journal of Medicine 301 501-502. (https://doi.org/10.1056/ NEJM197908303010912)

Gaytan F, Aceitero J, Lucena C, Aguilar E, Pinilla L, Garnelo P \& Bellido C 1992 Simultaneous proliferation and differentiation of mast cells and Leydig cells in the rat testis: are common regulatory factors involved? Journal of Andrology 13 387-397. (https://doi. org/10.1002/j.1939-4640.1992.tb03331.x)

Gill M, Sareen ML \& Sanyal SN 1991 Effect of H2-receptor antagonists, cimetidine and ranitidine on reproductive functions in male mice. Indian Journal of Experimental Biology 29 900-906.

Gupta A, Khosla R, Gupta S \& Tiwary AK 2004 Influence of histamine and $\mathrm{H} 1$-receptor antagonists on ejaculated human spermatozoa: role of intrasperm Ca2+. Indian Journal of Experimental Biology $\mathbf{4 2}$ 481-485.

Holtmann M, Gerstner S \& Schmidt MH 2003 Risperidone-associated ejaculatory and urinary dysfunction in male adolescents. Journal of Child and Adolescent Psychopharmacology 13 107-109. (https://doi. org/10.1089/104454603321666252)

Khan UW \& Rai U 2007 Differential effects of histamine on Leydig cell and testicular macrophage activities in wall lizards: precise role of $\mathrm{H} 1 / \mathrm{H} 2$ receptor subtypes. Journal of Endocrinology 194 441-448. (https://doi. org/10.1677/JOE-06-0225)

Kuzminov O, Ostapiv D \& Alekhina T 2014 Evaluation of cytotoxic action of antihistamines - desloratadine and loratadine - using bulls spermatozoa as a test object. Visnyk of Dnipropetrovsk University Biology, Medicine $\mathbf{5}$ 3-6. (https://doi.org/10.15421/021401)

Labbate LA 2008 Psychotropics and sexual dysfunction: the evidence and treatments. Advances in Psychosomatic Medicine 29 107-130.

Lejeune H, Chuzel F, Thomas T, Avallet O, Habert R, Durand P \& Saez J 1996 Paracrine regulation of Leydig cells. Annales d'Endocrinologie $\mathbf{5 7}$ 55-63. (https://doi.org/10.1159/000126627)

Leurs R, Chazot PL, Shenton FC, Lim HD \& de Esch IJ 2009 Molecular and biochemical pharmacology of the histamine $\mathrm{H} 4$ receptor. British Journal of Pharmacology 157 14-23. (https://doi.org/10.1111/j.14765381.2009.00250.x)

Martin-DeLeon PA 2015 Epididymosomes: transfer of fertility-modulating proteins to the sperm surface. Asian Journal of Andrology 17 720-725. (https://doi.org/10.4103/1008-682X.155538)

Mayerhofer A 2013 Human testicular peritubular cells: more than meets the eye. Reproduction 145 107-116. (https://doi.org/10.1530/REP-120497)

Mayerhofer A, Bartke A, Amador AG \& Began T 1989 Histamine affects testicular steroid production in the golden hamster. Endocrinology 125 2212-2214. (https://doi.org/10.1210/endo-125-4-2212)

Mondillo C, Patrignani Z, Reche C, Rivera E \& Pignataro O 2005 Dual role of histamine in modulation of Leydig cell steroidogenesis via HRH1 and $\mathrm{HRH} 2$ receptor subtypes. Biology of Reproduction 73 899-907. (https:// doi.org/10.1095/biolreprod.105.041285)

Mondillo C, Falus A, Pignataro O \& Pap E 2007 Prolonged histamine deficiency in histidine decarboxylase gene knockout mice affects Leydig cell function. Journal of Andrology 28 86-91. (https://doi.org/10.2164/ jandrol.106.000257) 
Mondillo C, Pagotto RM, Piotrkowski B, Reche CG, Patrignani ZJ, Cymeryng CB \& Pignataro OP 2009 Involvement of nitric oxide synthase in the mechanism of histamine-induced inhibition of Leydig cell steroidogenesis via histamine receptor subtypes in Sprague-Dawley rats. Biology of Reproduction 80 144-152. (https://doi.org/10.1095/ biolreprod.108.069484)

Nayeri KGD \& Kazerouni M 2002 The effect of cimetidine on serum testosterone, testes, prostate and seminal vesicle and its reversibility in rats. Journal of International Medical Research 1 1-9.

Nemetallah B, Howell R \& Ellis L 1985 Histamine and secondary autoimmune infertility in dark mink (Mustela vison). Archives of Andrology 15 79-82. (https://doi.org/10.3109/01485018508986895)

O'Reilly M, Alpert R, Jenkinson S, Gladue RP, Foo S, Trim S, Peter B, Trevethick M \& Fidock M 2002 Identification of a histamine H4 receptor on human eosinophils - role in eosinophil chemotaxis. Journal of Receptors and Signal Transduction Research 22 431-448. (https://doi. org/10.1081/RRS-120014612)

Ohtsu H 2010 Histamine synthesis and lessons learned from histidine decarboxylase deficient mice. Advances in Experimental Medicine and Biology 709 21-31. (https://doi.org/10.1007/978-1-4419-8056-4_3)

Pagotto RM, Monzon C, Moreno MB, Pignataro OP \& Mondillo C 2012 Proliferative effect of histamine on MA-10 Leydig tumor cells mediated through $\mathrm{HRH} 2$ activation, transient elevation in cAMP production, and increased extracellular signal-regulated kinase phosphorylation levels. Biology of Reproduction 87 1-10. (https://doi.org/10.1095/ biolreprod.112.102905)

Pap E, Racz K, Kovacs JK, Varga I, Buza E, Madarasz B, Foldes C, Szalai C, Watanabe T, Ohtsu H et al. 2002 Histidine decarboxylase deficiency in gene knockout mice elevates male sex steroid production. Journal of Endocrinology 175 193-198. (https://doi.org/10.1677/joe.0.1750193)

Par G, Szekeres-Bartho J, Buzas E, Pap E \& Falus A 2003 Impaired reproduction of histamine deficient (histidine-decarboxylase knockout) mice is caused predominantly by a decreased male mating behavior. American Journal of Reproductive Immunology $\mathbf{5 0}$ 152-158. (https://doi. org/10.1034/j.1600-0897.2003.00066.x)

Paria BC, Das N, Das SK, Zhao X, Dileepan KN \& Dey SK 1998 Histidine decarboxylase gene in the mouse uterus is regulated by progesterone and correlates with uterine differentiation for blastocyst implantation. Endocrinology 139 3958-3966. (https://doi.org/10.1210/ endo.139.9.6173)

Parsons M \& Ganellin R 2006 Histamine and its receptors. British Journal of Pharmacology 147 S127-S135. (https://doi.org/10.1038/sj.bjp.0706440)

Penttilae O \& Vartiainen A 1964 Acetylcholine, histamine, 5-hydroxytryptamine and catecholamine content of mammalian penile erectile and urethral tissue. Acta Pharmacologica Et Toxicologica 21 145-151. (https://doi.org/10.1111/j.1600-0773.1964.tb01776.x)

Pitt JM, Kroemer G \& Zitvogel L 2016 Extracellular vesicles: masters of intercellular communication and potential clinical interventions. Journal of Clinical Investigation 126 1139-1143. (https://doi.org/10.1172/JCl87316)

Raja M 1999 Risperidone-induced absence of ejaculation. International Clinical Psychopharmacology 14 317-319. (https://doi. org/10.1097/00004850-199909000-00007)

Robbins P \& Morelli A 2014 Regulation of immune responses by extracellular vesicles. Nature Reviews Immunology 14 195-208. (https:// doi.org/10.1038/nri3622)

Robbins P, Dorronsoro A \& Booker C 2016 Regulation of chronic inflammatory and immune processes by extracellular vesicles. Journal of Clinical Investigation 126 1173-1180. (https://doi.org/10.1172/JCl81131)

Safina F, Tanaka S, Inagaki M, Tsuboi K, Sugimoto Y \& Ichikawa A 2002 Expression of L-histidine decarboxylase in mouse male germ cells. Journal of Biological Chemistry 277 14211-14215. (https://doi. org/10.1074/jbc.M200702200)

Sasso-Cerri E 2009 Enhanced ERbeta immunoexpression and apoptosis in the germ cells of cimetidine-treated rats. Reproductive Biology and Endocrinology 7 127. (https://doi.org/10.1186/1477-7827-7-127)
Sasso-Cerri E \& Cerri PS 2008 Morphological evidences indicate that the interference of cimetidine on the peritubular components is responsible for detachment and apoptosis of Sertoli cells. Reproductive Biology and Endocrinology 6 18. (https://doi.org/10.1186/1477-7827-6-18)

Sasso-Cerri E \& Miraglia SM 2002 In situ demonstration of both TUNELlabeled germ cell and Sertoli cell in the cimetidine-treated rats. Histology and Histopathology 17 411-417. (https://doig.org/10.14670/ $\mathrm{HH}-17.411)$

Schreeb A, tażewska D, Dove S, Buschauer A, Kieć-Kononowicz K \& Stark H 2013 Histamine H4 receptor ligands. In Histamine H4 Receptor: A Novel Drug Target in Immunoregulation and Inflammation, pp 21-62. Ed H Stark. London: Versita.

Shefler I, Salamon P, Hershko A \& Mekori Y 2011 Mast cells as sources and targets of membrane vesicles. Current Pharmaceutical Design 17 3797-3804. (https://doi.org/10.2174/138161211798357836)

Simon C, Greening DW, Bolumar D, Balaguer N, Salamonsen LA \& Vilella F 2018 Extracellular vesicles in human reproduction in health and disease. Endocrine Reviews. (https://doi.org/10.1210/er.2017-00229)

Sinha RB, Banerjee P \& Ganguly AK 2006 Serum concentration of testosterone, epididymal mast cell population and histamine content in relation to sperm count and their motility in albino rats following $\mathrm{H} 2$ receptor blocker treatment. Nepal Medical College Journal 8 36-39.

Sullivan R 2016 Epididymosomes: role of extracellular microvesicles in sperm maturation. Frontiers in Bioscience 8 106-114. (https://doi. org/10.2741/s450)

Teixeira CE, Moreno RA, Ferreira U, Rodrigues Netto N Jr, Fregonesi A, Antunes E \& De Nucci G 1998 Pharmacological characterization of kinin-induced relaxation of human corpus cavernosum. British Journal of Urology $\mathbf{8 1}$ 432-436. (https://doi.org/10.1046/j.1464410x.1998.00533.x)

Thomas M \& Turner P 1983 Effect of chlorpheniramine, promethazine and cimetidine on human sperm motility in-vitro. Journal of Pharmacy and Pharmacology 83 761-762. (https://doi.org/10.1111/j.2042-7158.1983. tb02890.x)

Thurmond RL, Gelfand EW \& Dunford PJ 2008 The role of histamine $\mathrm{H} 1$ and $\mathrm{H} 4$ receptors in allergic inflammation: the search for new antihistamines. Nature Reviews Drug Discovery 7 41-53. (https://doi. org/10.1038/nrd2465)

Ückert S, Wilken M, Stief C, Trottmann M, Kuczyk M Becker A 2012 Is there a significance of histamine in the control of the human male sexual response? Andrologia 44 538-542. (https://doi.org/10.1111/j.14390272.2011.01222.x)

Van Thiel DH, Gavaler JS, Heyl A \& Susen B 1987 An evaluation of the anti-androgen effects associated with $\mathrm{H} 2$ antagonist therapy. Scandinavian Journal of Gastroenterology 136 24-28. (https://doi. org/10.3109/00365528709094482)

Wagner W, Ichikawa A, Tanaka S, Panula P \& Fogel WA 2003 Mouse mammary epithelial histamine system. Journal of Physiology and Pharmacology 54 211-223.

Wang C, Lai CL, Lam KC \& Yeung KK 1982 Effect of cimetidine on gonadal function in man. British Journal of Clinical Pharmacology 13 791-794. (https://doi.org/10.1111/j.1365-2125.1982.tb01867.x)

Zieher LM, Debeljuk L, Iturriza F \& Mancini RE 1971 Biogenic amine concentration in testes of rats at different ages. Endocrinology 88 351-354. (https://doi.org/10.1210/endo-88-2-351)

Received 9 November 2017

First decision 18 December 2017

Revised manuscript received 21 February 2018

Accepted 5 March 2018 